\title{
CORRESPONDENCE
}

\section{The structure at Abereiddy Bay, Pembrokeshire}

SIR,-I agree with the contributions of Waltham (1971) and Black et al. (1971) in their general interpretation of the structure and stratigraphy of the Ordovician rocks exposed at Abereiddy Bay: the cleavage is approximately axial planar and can be used, particularly with the supporting stratigraphical evidence of Black $e t$ al., to indicate that the beds

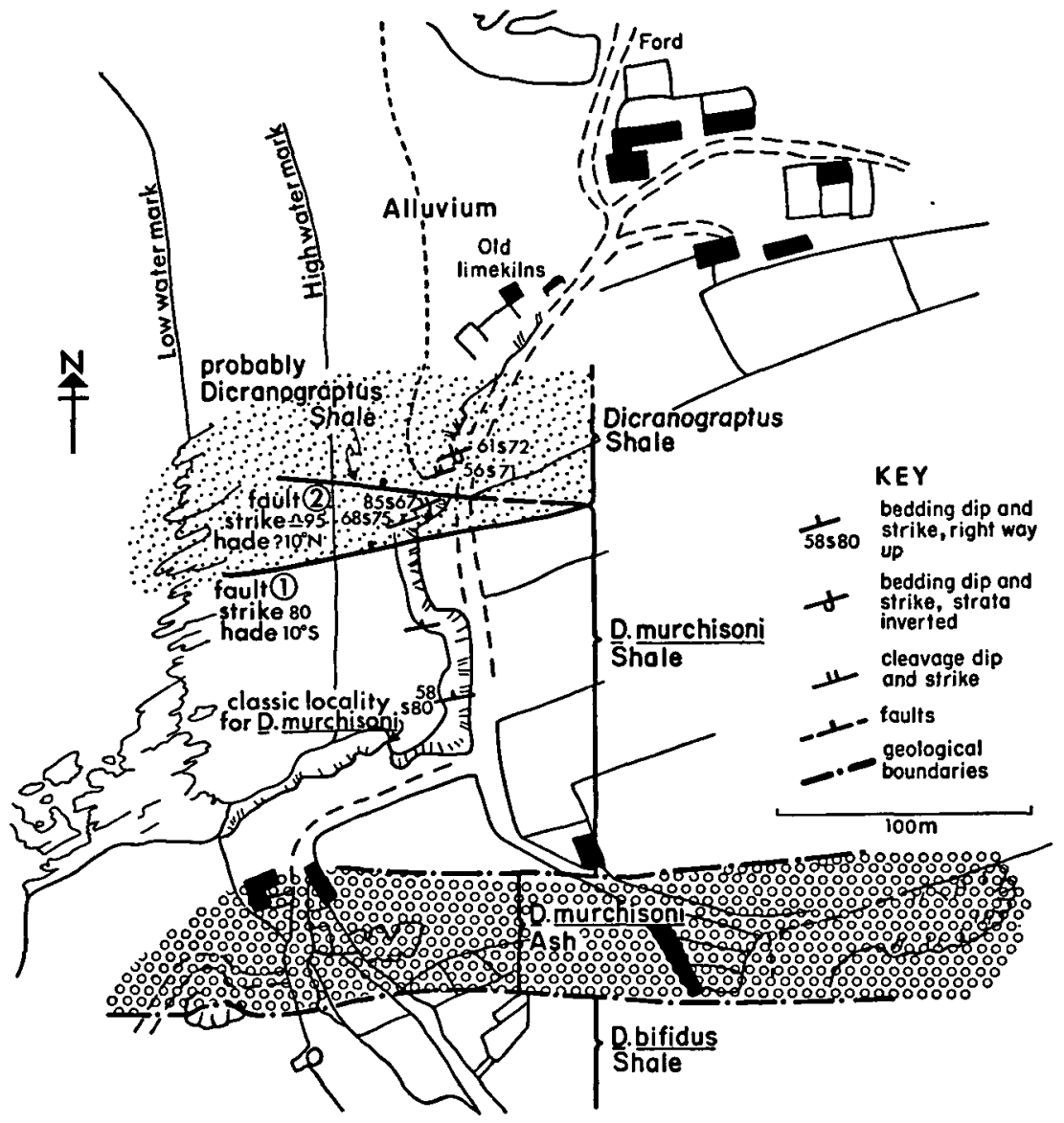

Figure 1.

on the north side of the bay are inverted. However, the cleavage/bedding relationships on the south side of the bay indicate that the structure is more complicated than suggested by Waltham's Figures 1 and 2.

Figure 1 herein depicts my interpretation of the exposures. Between the old limekilns and the fault labelled 2 are some tens of metres of dark shales lithologically similar to the Dicranograptus Shales and which have recently yielded poor specimens of

Geog. Mag. 110 (2), 1973, pp. 185-187. Printed in Great Britain. 
Dicranograptus sp. and other badly preserved graptolites in the middle of the exposed beds. The cleavage in this part of the section dips northwards at a lower angle than the bedding (Fig. 1, pl. 1a) indicating that the strata are inverted, a conclusion supported also by small-scale sedimentary structures ('cross bedding' in the siltstone bands). This situation obtains right up to the brecciated zone along the line of fault 2 . There is a suggestion in the cliff that the fault hades to the north at about $10^{\circ}$ : the brecciated and veined zone, forming a gulley on the foreshore, varies from 1-3 $\mathrm{m}$ in width.

Immediately south of fault 2 the bedding cleavage relationship is reverse of the above, cleavage being steeper than bedding (Fig. 1, pl. 1b). All the rock exposed between faults 1 and 2 exhibits this feature clearly except very close to fault 1 , where cleavage becomes

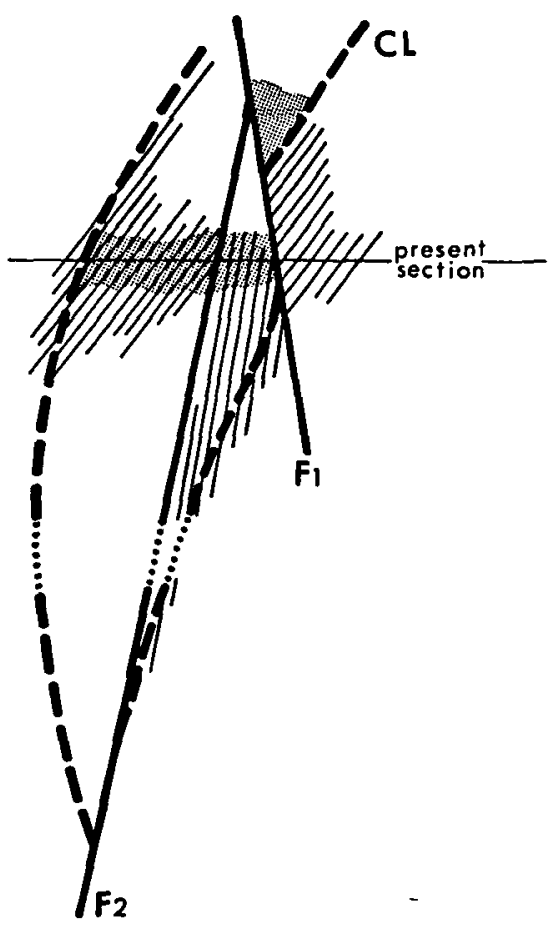

Fig 2a

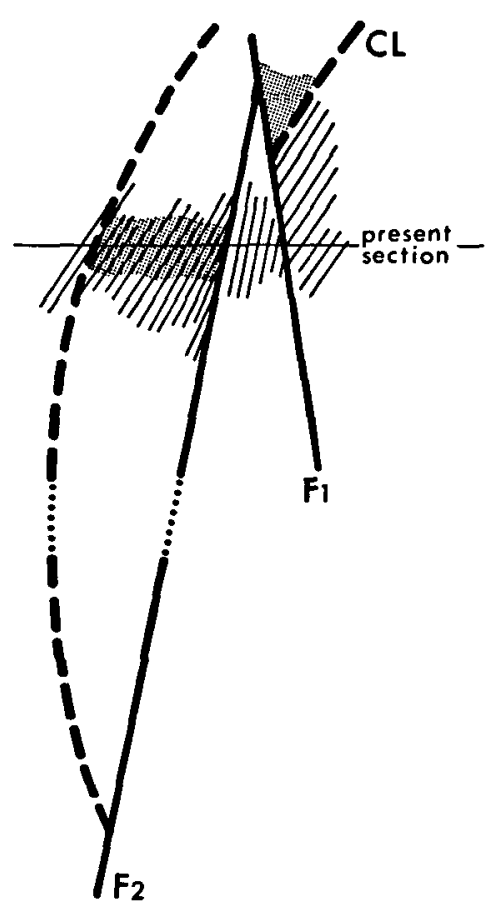

Fig $2 b$

Figure 2. Suggested interpretation of present arrangement of faults, fold, bedding and cleavage: $a$, on the assumption that the strata between faults 1 and 2 are of Dicranograptus Shale age; b, on the assumption that they are pre-Castell Limestone. CL, Castell Limestone; F1, F2, faults 1 and 2; fine shading, cleavage, stipple, Dicranograptus Shale; unornamented, murchisoni and bifidus Shale. Not to scale but dips of beds, faults and cleavage correct.

nearly parallel to the bedding. This latter situation is common throughout the rest of the coast section depicted on Figure 1 where the cleavage is either parallel to or slightly steeper than the bedding, a factor contributing largely to the ease with which murchison zone graptolites can be collected at the classic shore locality. The beds between faults 1 and 2 have yielded no fossils to the writer but lithologically they are similar to the Dicranograptus shales on the north side of the bay.

With reference to the syncline defined by Waltham and by Black $e t a l$. it seems the axis should be traced through this faulted area on the south side of the bay and not, as 
Geol. Mag. Vol. 110, 1973, Rickards, Plate 1, facing page 186.

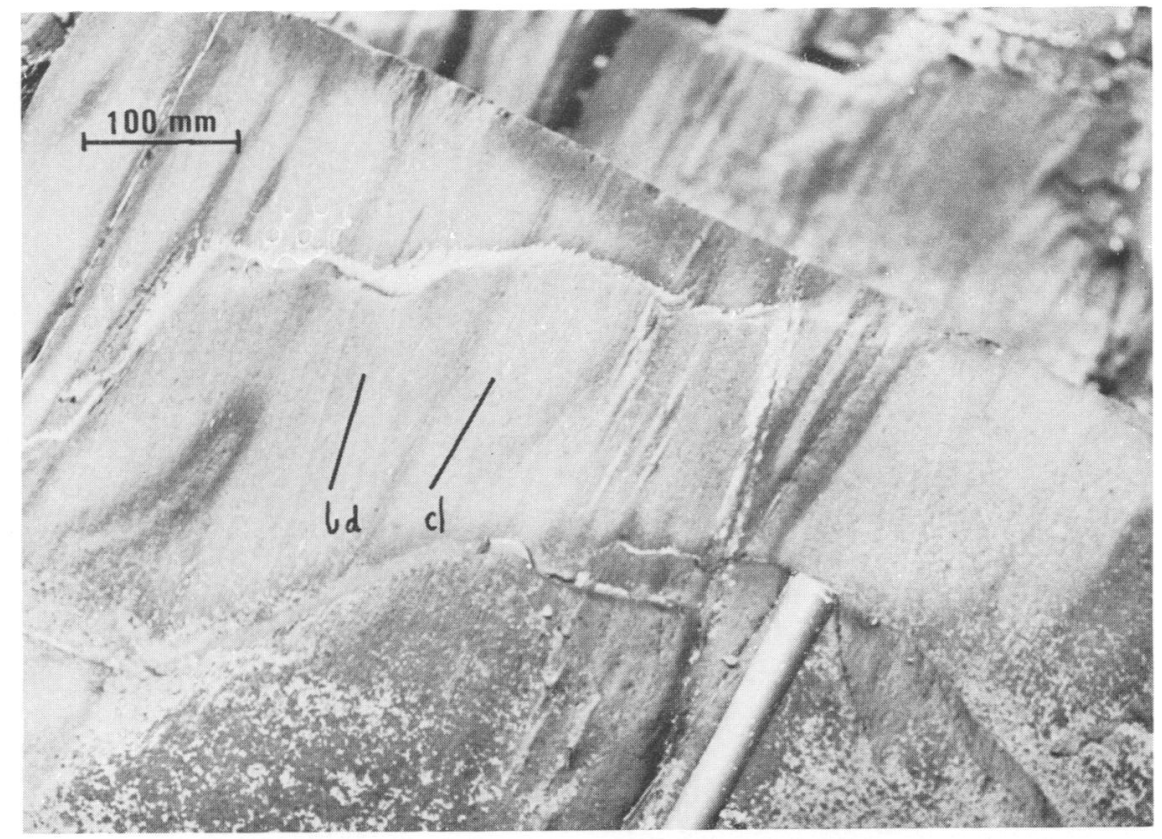

a

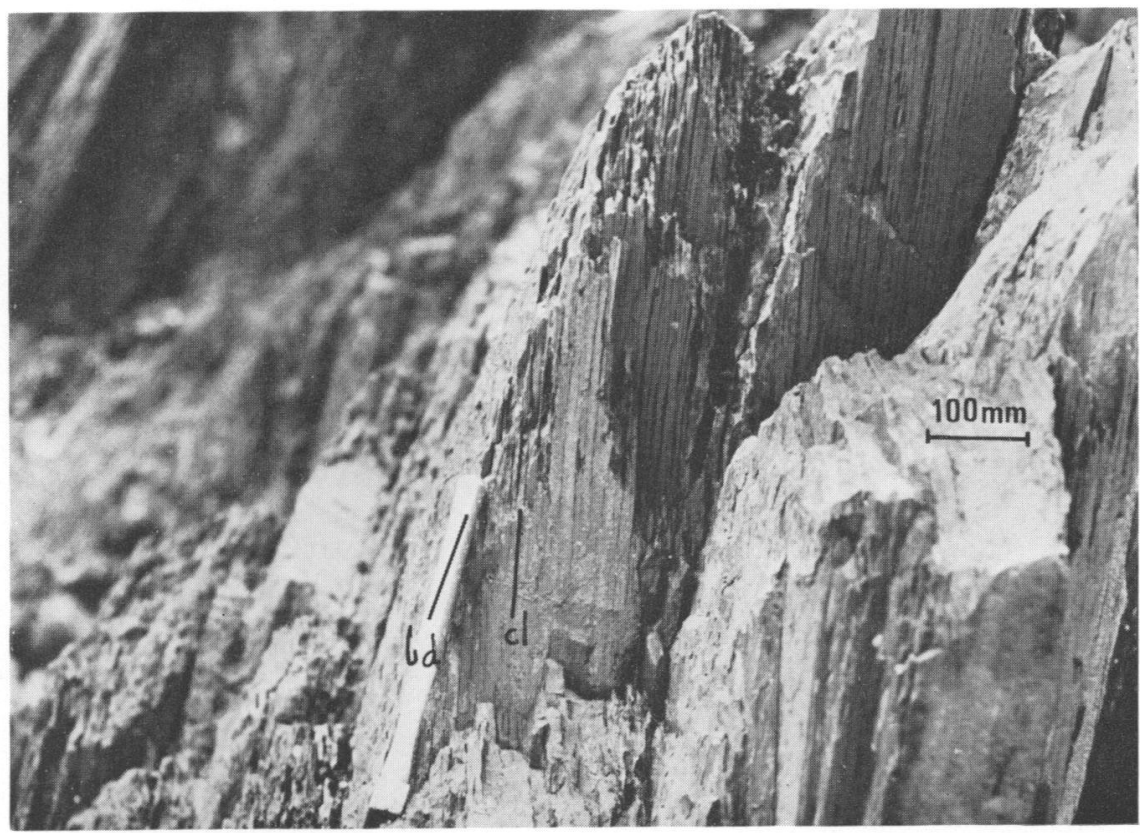

b

Plate 1. Structure at Abereiddy Bay, Pembrokeshire.

Plate $1 a$. Cleavage bedding relation north of fault 2 .

Plate $1 b$. Cleavage bedding relation between faults 1 and 2 .

Scale line in each case represents $100 \mathrm{~mm}$; bd, bedding direction; cl, cleavage direction. 
depicted by Waltham, through the area of alluvium occupying the coast in the middle of the bay. It is possible that the hidden solid geology in the centre of the bay may eventually be shown to include more faults or folds (although the latter seems unlikely) but the above story will probably remain correct: that strata north of fault 2 are inverted and south of this fault are the right way up.

The significance of having an essentially faulted core to the overturned syncline is that the Castell limestone need not thin out southwards. It is quite possible that it is faulted out in the manner depicted on Figure 2a particularly if the amplitude of the syncline is of the very likely order illustrated by Waltham (1971, Fig. 2). Should the dark shales between faults 1 and 2 be shown to be older than the Dicranograptus Shales, say, of murchisoni shale age then Figure $2 \mathrm{~b}$ is a possible interpretation of the observations. In slight support of this possibility is downdragging of the beds associated with fault 1 which suggest that the strata in the block have been moved upwards.

\section{References}

Black, W. W., Bulman, O. M. B., Hey, R. W. \& Hughes, C. P. 1971. Ordovician stratigraphy of Abereiddy Bay, Pembrokeshire. Geol. Mag. 108, (6), 546-8.

Waltham, A. C. 1971. A note on the structure and succession at Abereiddy Bay, Pembrokeshire. Geol. Mag. 108 (1), 49.

Department of Geology

R. B. RICKARDS

Sedgwick Museum

Downing Street

Cambridge CB2 3EQ

1 st January 1973 